\title{
Structural Equation Modelling Using AMOS: Confirmatory Factor Analysis for Taskload of Special Education Integration Program Teachers
}

\author{
Mohamad Zaid Bin Mustafa, Mohd Norazmi Bin Nordin*, Abdul Rasid Bin Abdul Razzaq \\ Faculty of Technical and Vocational Education, Universiti Tun Hussein Onn Malaysia, Johor, Malaysia
}

Received October 22, 2019; Revised November 18, 2019; Accepted November 19, 2019

Copyright $\mathrm{C} 2020$ by authors, all rights reserved. Authors agree that this article remains permanently open access under the terms of the Creative Commons Attribution License 4.0 International License

\begin{abstract}
This study explores the factors leading to the onset of task load among teachers of Special Education Integration Program. As we know, task load is an important issue among special education teachers in general and teachers of Special Education Integration Program in particular. This issue has been going on for a long time. Some studies have found that there are a number of factors that influence the task load of teachers of Special Education Integration Program, including leadership issues at school, working conditions, work intensity and also resources or facilities. In this study, a fully quantitative approach is used to determine factors in the task load of teachers of Special Education Integration Program. The questionnaire was distributed online using the Google form platform to randomly collect data from 400 respondents across Malaysia. The data obtained were then analysed using Structural Equation Modelling (SEM) using AMOS 21 application. Confirmatory Factor Analysis was performed to obtain factor loading for each element obtained namely work type, work environment and time. The analysis results show that the two factors reflect the appropriate fit and meet all the criteria for validation. While the work type factor does not show compatibility. There have been several domestic and overseas studies examining the factors of special education teacher loading, but the application of the SEM analysis approach using AMOS is still underdeveloped. Therefore, the findings of this study can further confirm previous findings on this issue.
\end{abstract}

Keywords Structural Equation Modelling, Confirmatory Factor Analysis, Task Load, Special Education, Special Education Integration Program

\section{Introduction}

Teachers' task load is composed of a multitude of often competing responsibilities (Charbonnier, 2015). The task load of a teacher occurs when a teacher is forced to perform many tasks at a time such as basic teaching task and other additional tasks (Corry, 2015). The effects of task load are on emotional exhaustion, presenteeism, job satisfaction and performance (Huyghebaert et. al., 2018). Wakoli (2016) states that the load of teacher task is due to school management, employment conditions and job categories. In identifying and ensuring the suitability of a factor for a particular construct, Confirmatory Factor Analysis (CFA) must be carried out (Barbara, 2010). The compatibility of each factor needs to be tested and verified so that the obtained factors match the constructs. In this study, factors in the task load of PPKI teachers were tested to determine the compatibility and those had implications for the results of the study. Through some previous studies such as Norizan et. al., (2013), Junaidah and Nik Rusila (2013) and John Anderson (2017) found that there are three factors influencing PPKI teachers' task load - type of work, time and working environment.

\section{Background Research}

Special Education Integration Program teachers today are burdened with their schoolwork. It is very important for teachers not to be overwhelmed with the extra task, as this will leave the teacher's focus on teaching disrupted. Disruptions in this teaching will affect the performance of special education students in the classroom. In many studies, such as studies of Junaidah and Nik Rusila (2013) in Penang, Malaysia, and Norizan et al., (2013) in Perak, Malaysia have found that special education teachers are not able to give proper focus to the teaching of special needs students. Although this issue has been going on for a long time, the solution to the problem has not been found. There are a number of factors that lead to increased 
task load among PPKI teachers in Malaysia. Among these is the type of work that is given to PPKI teachers. According to Norizan et al., (2013), most jobs that burden Special Education Integration Program teachers are those that do not involve special needs students. In addition, the work environment is also an important factor in this issue. According to the study by Junaidah and Nik Rusila, (2013), a conducive working environment, good administrative support and communication can reduce the burden of PPKI teachers' task load. Next is the time-related factor. A study by John Anderson (2017) explains that the increase in the transfer of special education teachers to the mainstream is due to failure to complete multiple assignments at a time. Therefore, this study was conducted to meet the objectives and research questions as follows:

a. Research objective

i. Validate factor compatibility for Special Education Integration Program teachers' task load.

b. Research questions

i. Can the factors for Special Education Integration Program teachers' task load be determined by their consistency?

\section{Literature Review}

Several studies on the burden of the special education teacher's work have been carried out locally and abroad. The burden of special education tasks occurs when teachers take on a variety of tasks, whether related to special education or not at any given time (Norizan et al., 2013). The type of assignment received will be a burden to the teacher if it overlaps with each other (Junaidah \& Nik Rusila, 2013). Meanwhile, John Anderson (2017) states that the burden of special education teachers' duties is that they are tasked with affecting their true role in teaching MBK. Rabayah et al., (2010) and Massithah (2009) point out that assignments outside of special education received the potential to add additional burden to teachers.

Rosnah and Siti Nur Fatihah (2018) in their study found that task load is a factor for performance of teachers in school. A study conducted in several primary schools in Sabah involving 68 teachers showed that there is a perception among teachers that the three main factors influence their work performance in school, task load, work environment and personal problem. The findings showed that the three factors were moderated by respondents, as follows, (task load: $\mathrm{M}=3.1454, \mathrm{SD}$ $=.35822$, work environment: $\mathrm{M}=2.9592, \mathrm{SD}=.32403$, personal problem: $\mathrm{M}=3.0441, \mathrm{SD}=.24648$ ). If examined, this study demonstrates that PPKI teachers' task load can be reduced if the work environment and job situation are improved, as agreed by Amalina and Azita (2016). A study by Erica and Raymond (2009) found that the time frame for assignments to be completed made special education teachers rush to complete their assignments. Amalina and Azita's (2016) study of factors that led to the pressure of special education teachers found that special education teachers did not have enough time to complete their assignments in one particular period. This study also explained that the high burden of PPKI teachers' duties beyond their actual assignments can affect their teaching focus (Rabayah et al., 2010).

A study by Nelson, Melissa and Kathleen (2014) showed that special education teachers experience burns out due to task load, student circumstances and even support from administrators. Synthesis was carried out by researchers based on studies from 1979 to 2013. Quantitative research based on the documents obtained shows that the participants were composed entirely of special education teachers. The analysis of the study provided the basis support for district level education management in addressing burns out issues among special education teachers. This study demonstrates that a conducive working environment through the support provided by the administrators to teachers of PPKI can prevent the occurrence of high burden of teachers' work (Ruzanna and Suhaida, 2013).

\subsection{Taylor's Theory of Scientific Management}

Taylor in his study identified several weaknesses in management that need to be improved, namely lack of knowledge of management responsibilities, lack of effective standard work, failure to plan work scopes, unscientific management decisions and lack of job-related research balanced. Therefore, Taylor, in 1911, emphasizes six fundamentals in management for his theory, namely movement planning, job specialization, planning and scheduling, staff selection and hiring and matching salaries (Taylor, 1911). Hakan Turan (2015), Yimeng Su (2017) and Khairul Faizi (2018) state that the introduction of ideas in this theory is related to the primary purpose of producing productive workers. In realizing this purpose, the theory emphasizes that management must be wise in establishing where a worker should be, the type of work that is appropriate to the employee and the needs to be met. In formulating quality management as well as caring for the welfare of employees, this theory emphasizes on three aspects namely quality, flexibility and motivation (Salvatore Ferraro, 2016). Yimeng Su (2017) points out that quality is a priority in management, providing the right training and ability to realize this goal, but another aspect that needs to be addressed is the equitable distribution of tasks between the workers and the appropriate rewards.

In understanding this indicator, Hakan Turan (2015) has previously proposed the basic principles of this theory of employee reward, scientific management and employee motivation. Looking at the context of teachers, Khairul 
Faizi (2018) sees the application of this theory to a minimum as it helps to increase productivity and realize their potentials. In the context of teachers' work, administrators should understand this theory by emphasizing the principles of time and movement expressed in order to avoid the burden of teacher work (Richard, 2012). School administrators also need to conduct research on work type, work environment and time for the purpose of reducing teacher task load (Roopinder, 2018).

\subsection{Henry Fayol's Theory of Management}

Henry Fayol's Theory of Management is a precursor to modern management theory which is a worldwide reference, built by Fayol in 1949. According to Herve Dumez (2018), these found theories help humans to apply scientific approaches to practicing proper management. In successful school management, this theory proposes 14 principles of management that must be adhered to and guided (Priyono, 2017). These principles emphasize the adaptation and importance of caring for the well-being of teachers. The first principle is that task sharing emphasizes the importance of assigning tasks according to one's expertise to increase productivity (Herve Dumez, 2018). The second principle is the balance of power and responsibility that emphasizes the concept of equilibrium in the ownership of power as well as the responsibilities that must be exercised (Joshua \& Rina, 2016). The principle of discipline requires all individuals involved in the school including headmasters as administrators and teachers as subordinates to maintain discipline in all matters (Herve Dumez, 2018). Joshua and Rina (2016) explain that the fourth principle in this theory requires executives to accept and obey only one parties' instruction to avoid conflict or overlap. The fifth principle, as explained by Kullabs (2018), is that all teachers need to have a common goal in achieving a task. Furthermore, the sixth principle, according to Yumeikochi (2011), states that each individual involved should prioritize the achievement of the school organisation rather than the self-achievement and self-interest.
The seventh principle according to Herve Dumez (2012) is that a fair emolument is the condition in which salaries or wages received must correspond to the contribution of teachers. According to Yumeikochi (2011), care and recognition should also be given to the rightful individual. The eighth principle is centralization where Kullabs (2018) argues that the task structure needs to be centralized and that implementation needs to be done in a less demanding manner. Ferry Roen (2011) describes the ninth principle as individuals in schools need to be aware of and carry out their tasks in a hierarchy and not be able to surpass or diminish their actual role. Budi Kho (2017) sees the tenth principle as the need to bind every individual in the organisation to work in accordance with rules intended to avoid problems. The eleventh principle emphasizes the justice aspect of every matter, especially in the reduction and determination of assignments to prevent high-level task load problems among teachers (Budi Kho, 2017). The twelfth principle suggests that school principals are responsible for creating a conducive working environment so that teachers can achieve their job satisfaction and prevent them from making the decision to quit (Joshua \& Rina, 2016). The thirteenth principle proposes that principals as school leaders should give teachers freedom to perform tasks and avoid burdening teachers (Budi Kho, 2017). The latter principle emphasizes the importance of working as a team and the headmasters as leader should always create a work environment that is full of unity (Joshua \& Rina, 2016).

According to Ferry Roen (2011), these principles are fundamental for school leaders to practice appropriate interactions with teachers - job allocation, balance of power and responsibility, displacement, union direction, direction of organisation, prioritizing organizational interests over individual interests, equitable emoluments, centralization, duty hierarchy, regulation, justice, staff stability, initiative and the spirit of unity. The principles presented are very useful to school leaders especially teachers in planning and practicing good management so that teachers can be fair in terms of respect and even division of duties (Fayol, 1949). 
Confirmatory Factor Analysis for Taskload of Special Education Integration Program Teachers

Table 1. Summary of Management Theories for Teacher Task Load Factors

\begin{tabular}{|c|c|c|c|c|}
\hline \multirow{2}{*}{ No } & \multirow{2}{*}{ Theory of Management } & \multicolumn{3}{|c|}{ Factor } \\
\hline & & Factor 1 & Factor 2 & Factor 3 \\
\hline 1 & $\begin{array}{c}\text { Taylor's Theory of Scientific } \\
\text { Management }\end{array}$ & \begin{tabular}{ll} 
& \multicolumn{1}{c}{ Time: } \\
- & Enough rest \\
- & work schedule \\
- & Time allocation is \\
appropriate
\end{tabular} & $\begin{array}{ll} & \text { Type of work: } \\
\text { - } & \text { Eligibility } \\
\text { assignment } & \\
\text { - } & \\
\text { assignments as } \\
\text { needed }\end{array}$ & $\begin{array}{l}\text { Work environment: } \\
\text { - } \text { guidance and } \\
\text { training } \\
\text { motivation } \\
\end{array}$ \\
\hline 2 & $\begin{array}{c}\text { Henry Fayol's Theory of } \\
\text { Management }\end{array}$ & $\begin{array}{c}\text { Time: } \\
\text { - } \quad \text { - evenly distributed tasks } \\
\text { - } \quad \text {-according to expertise }\end{array}$ & $\begin{array}{l}\text { Type of work: } \\
\text { - } \quad \text { Administrator } \\
\text { support }\end{array}$ & $\begin{array}{l}\text { Work environment : } \\
\text { - } \\
\text { - } \\
\text { - } \\
\text { Full facilities } \\
\text { Be together }\end{array}$ \\
\hline
\end{tabular}

\section{Research Methodology}

This study uses the full quantitative method in data collection. According to Saul (2019), quantitative methods are approaches to quantitative data and involve numerical measurement. Researchers use a set of questionnaires built to randomly distribute to PPKI teachers through the Google form platform. A total of 450 sets of questionnaires online through a Google form link were distributed randomly to special education integration programs teachers throughout Malaysia. Of these, 400 sets of completed questionnaires were received for analysis. With this amount, the response rate can be recorded at $89 \%$. This response rate is acceptable based on Fryrear (2015) recommendation of over $80 \%$. The questionnaire set was analysed using the Structural Equation Modelling (SEM) approach. SEM is the second generation of multivariate analysis in the study (Zainudin, 2015). This method is very popular with academics as well as researchers in analysing the data obtained through questionnaires. The use of AMOS applications to adapt this SEM method is very appropriate as the analysis performed will provide more accurate results (Barbara, 2010).

The tests used to determine the compatibility of the factors involved were CFA tests for each factor. The main criterion for determining this compatibility is to look at the loading factor value that should be $\geq 0.50$, not be $\geq$ 1.00 , and must be positive. The other criteria proposed for this fit are divided into 3 fitness validity namely, fitness index, Convergent Validity and Construct Validity. For fitness index, the RMSEA value should be $\leq 0.08$ (Byrne, 2001), while the GFI, CFI and TLI values should be $\geq$ 0.90 (Bentler, 1990; Hatcher, 1994). Relative/Normed Chi-Square values must be approximately $\leq 5.0$ (Bentler, 1990). For validity assessment, the Convergent Validity (Average Variance Extracted-AVE) and Construct Validity measurements need to be met. According to Kline (2005), the value of AVE that can determine compatibility is at least 0.50 , while Fornell \& Larcker (1981) suggest that the AVE value in meeting the Convergent Validity measurement requirements is $\geq 0.5$. Next is the criterion for reliability measurement. This criterion involves a Composite Reliability value of $\geq 0.7$.

\section{Findings}

The findings show that the CFA analysis conducted for teacher task load did not meet the criteria of RMSEA = 0.121, Relative/Normed Chi-Square (6.859), while GFI, CFI and TLI values did not reach $\leq 0.90$, as indicated in Figure 1. This is because there is a negative factor loading value of -0.24 for the type of work. Therefore, this CFA needs to be re-run for improvements through fit indices (Zainudin, 2015). After modification made to the CFA, the correlation value was achieved at RMSEA $=0.077$, Relative/Normed Chi-Square (3.393), while the CFI and TLI values reached $\geq 0.90$, as shown in Figure 2 . However, the loading factor value for this type of work is still in negative value. This indicates that the type of work contributes negatively to the PPKI teacher's task load. 


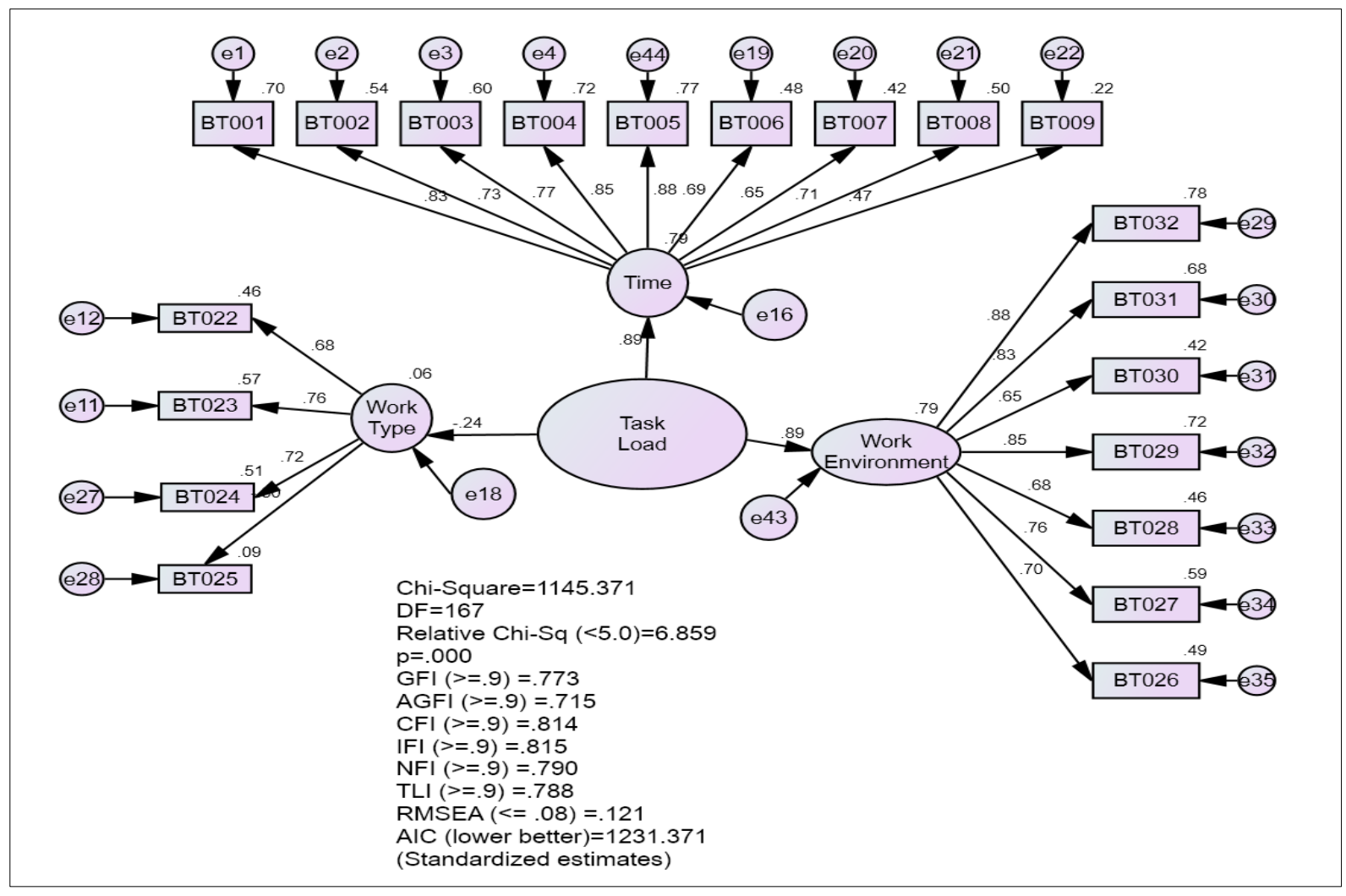

Figure 1. CFA for Task Load (Original)

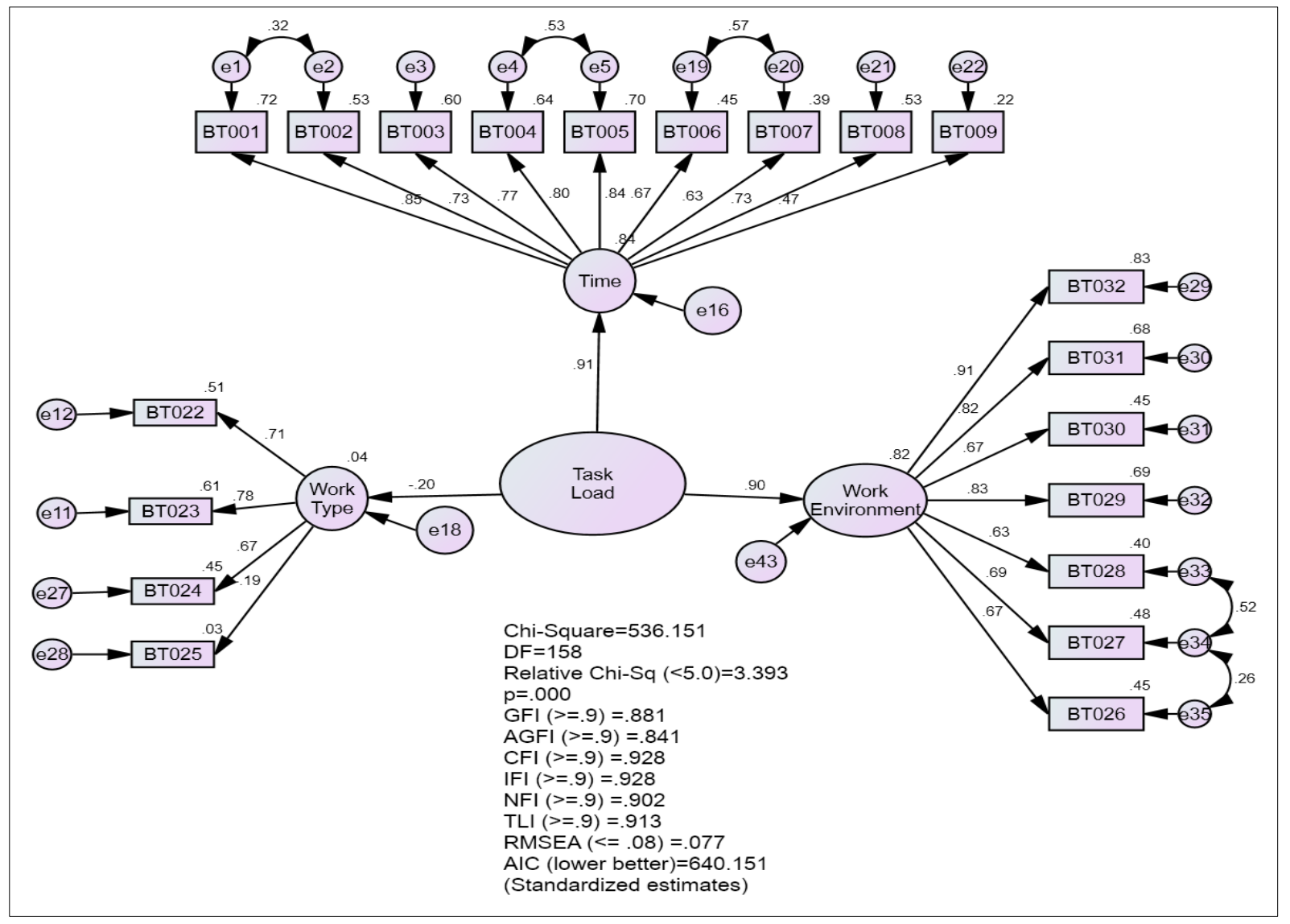

Figure 2. CFA for Task Load (Modified) 


\section{Discussion}

From the findings of the study, it can be said that Special Education Integration Program teachers' task load is influenced by time factors. The average respondent agrees that the amount of time given to them in their assignments puts them at a disadvantage to complete the task. In addition, assignments beyond working hours also make the time factor major support for this issue. The same goes for the work environment factor. The majority of respondents agreed that the work environment was not conducive, lack of support and lack of cooperation made them burden with their work. For them, a conducive working environment, appreciation, good communication and administrative support can reduce the burden of the tasks they carry. However, the type of work received is not a burden on Special Education Integration Program teachers. Most of them are willing to do whatever task they are assigned. Special Education Integration Program teachers also have no problems in performing various types of work. However, the issue of the task load of these Special Education Integration Program teachers comes from the factors of work environment and time.

\section{Conclusions and Suggestion}

Based on the findings of this study, it can be concluded that the issue of Special Education Integration Program teachers' task load is still ongoing and has not yet been found. Given the emphasis on the factors was gained through this study, it is hoped that stakeholders such as school leadership can look at this issue and improve their leadership. Through this study, the researchers suggested that school management can focus on the management and distribution of duties to teachers of Special Education Integration Program by examining the policies of the Ministry of Education Malaysia which wants to reduce the burden of teacher work. For further studies, it is proposed that further exploration of these factors be used by qualitative methods to obtain more data. This study also suggested some other constructs such as teacher job satisfaction and school leadership.

\section{Closing}

The issue of the task load of PPKI teachers should be given due attention by stakeholders such as the school leadership, the state education department and the education ministry so that it does not continue. This task load can have an impact on productivity, work motivation and job satisfaction. All of these effects will have an impact on MBK's future incarceration.

\section{Acknowledgements}

The authors would like to thank Ministry of Education Malaysia for supporting this research under Fundamental Research Grant Scheme Vot No. K207, FGRS/1/2019/SS109/UTHM/02/1 and partially sponsored by Universiti Tun Hussein Onn Malaysia.

\section{REFERENCES}

[1] Amalina Binti Razali \& Azita binti Ali (2016). Faktor-Faktor Yang Mempengaruhi Tahap Stres Guru Pendidikan Khas. Active Online Journal, UTHM, 8, 1

[2] Barbara M. Byrne (2010). Structural Equation Modeling with AMOS: Basic Concepts, Applications, and Programming Second Edition. New York, USA: Routledge Taylor \& Francis Group.

[3] Budi Kho (2017). 14 Prinsip Manajemen Menurut Henri Fayol. Retrieved from https://ilmumanajemenindustri.com/ 14-prinsip-manajemen-menurut-henri-fayol/at29November 2018.

[4] Byrne, B. M. (2010). Multivariate applications series. Structural equation modeling with AMOS: Basic concepts, applications, and programming (2nd ed.). New York, NY, US: Routledge/Taylor \& Francis Group.

[5] Charbonnier, E. (2015). How much time do teachers spend on teaching and non-teaching activities? Education Indicators in Focus: OECD.

[6] Corry (2015). Workload Analysis Teachers in Development Education (Case Studies Teachers in Junior High School District of Pamatang Sidamanik). International Journal of Academic Research in Business and Social Sciences January 2015, Vol. 5, No.1: 399-411.

[7] Erica Nance, Raymond L. Calabrese (2009). Special Education Teacher Retention And Attrition: The Impact Of Increased Legal Requirements. International Journal of Educational Management, Vol. 23 Issue: 5, pp. 431-440.

[8] Fayol, H. (1949). General and Industrial Management. (Trans. C Storrs). London: Pitman.

[9] Ferry Roen (2011). Henry Fayol: Pencarian Terhadap Bentuk Teori Manajemen. Retrived from http://perilakuorg anisasi.com/henry-fayol-1841-1925.html at 29 November 2018.

[10] Fornell, C. D., \& Lacker, D. F. (1981). Evaluating Structural Equation models with Unobservable Variables and Measurement Error. Journal of Marketing Research, 18, 39-50. http://dx.doi.org/10.2307/3151312

[11] Fryrear, A. (2015). What's a Good Survey Response Rate? Retrived from https://www.surveygizmo.com/resources/bl og/survey-response-rates/ at 16 November 2019.

[12] Hakan Turan (2015). Taylor's Scientific Management Principles: Contemporary Issues in Personnel Selection Period. Journal of Economics, Business and Management, Vol. 3, No. 11, November 2015: 1102-1105. 
[13] Hatcher, L. (1994) A Step-by-Step Approach to Using the SAS System for Factor Analysis and Structural Equation Modeling. SAS Institute, Inc., Cary.

[14] Hervé Dumez (2018) Henri Fayol. Performativity of His Ideas And Oblivion of Their Creator. i3 Working Papers Series, 18-CRG-01.

[15] Huyghebaert. T., Gillet. N., Beltou. N, Tellier. F., and Fouquereau. E. (2018). Effects of workload on teachers' functioning: A moderated mediation model including sleeping problems and over commitment. Stress \& Health. Vol. 34 (5). 601-611.

[16] John Anderson, (2017). A Workload Analysis Formula to Increase the Retention of Special Education Teachers in Minnesota. Culminating Projects in Special Education. 37.

[17] Junaidah Mohamad dan Nik Rosila Nik Yaacob, (2013). Kajian Tentang Kepuasan Bekerja Dalam Kalangan Guru-Guru Pendidikan Khas. Asia Pacific Journal of Educators and Education, Vol. 28 :103-115.

[18] Khairul Faizi bin Ahmad Kamil (2018). Bahagian Ketiga Mengadaptasi Teori Pengurusan Ke Dalam Pentadbiran Pas. Retrieved from www.khairulfaizi.net at 29 November 2018.

[19] Kline, R. B. (2011). Principles and Practice of Structural Equation Modelling 3rd Edition. New York: Guilford Press.

[20] Kullabs (2018). Note on Fayol's Administrative Management Theory: Concept and Principles. Retrieved from https://www.kullabs.com/classes/subjects/units/lesso ns/notes/note-detail/4439 at 29 November 2018

[21] Massithah (2009). Hubungan Pengajaran Guru Besar Dengan Komitmen Kerja Guru Di Sekolah Rendah Luar Bandar. The International Journal of Learning. Volume 16:21-29.

[22] Nelson C. Brunsting, Melissa A. Sreckovic, Kathleen Lynne Lane, (2014). Special Education Teacher Burnout: A Synthesis of Research from 1979 to 201. Education and Treatment of Children, Volume 37, Number 4, November 2014, pp. 681-711.

[23] Norizan Abdul Ghani, Zahidah Anisah Mohamad dan Che Wan Takwa Che Wan Abu Bakar (2013). Teachers' Challenges in Educating Special Children in Special Classes of Three Selected Primary Schools, Kuala Terengganu, Terengganu, Malaysia. Advances in Natural and Applied Sciences, 7(3): 284-291, 2013.

[24] Priyono (2007). Buku Pengantar Manajeman. Universitas Bina Darma : Zifatama Publisher.

[25] Rabayah Yahaya, Mohd Zuri Ghani, Rahimi Che Aman, Aznan Che Ahmad, Zainudin Mohd Isa, Hairulnizam Ismail dan Aswati Hamzah, (2010). Stress Dalam Kalangan Guru Pendidikan Khas. Journal MEDC Volume 6 2010: 1-11.

[26] Richard L. Daft (2012), New Era of Management, International Edition, South Western Cengage Learning. Bab 2.

[27] Roopinder Oberoi (2018). Frederick Wilson Taylor's Scientific Management Theory. Retrieved from www.epgp.inflibnet.ac.in at 29 November 2018.

[28] Ruzanna Mohd Nasir and Suhaida Abd Kadir (2013). Beban Tugas Guru Teknikal Di Sekolah Menengah Pendidikan
Khas Vokasional (Smpkv). Seminar Pasca Siswazah Dalam Pendidikan (Greduc 2013): 466-470.

[29] Salvatore Ferraro (2016). Frederick Taylor's other Principles. International Journal of Business and Social Science Vol. 7, No. 11; November 2016: 24-27.

[30] Saul M. L (2019). What's the difference between qualitative and quantitative research? Retrieved from https://www.sim plypsychology.org/qualitative-quantitative.html, at 13 August 2019.

[31] Taylor, Frederick Winslow (1911), The Principles of Scientific Management, New York, NY, USA and London, UK: Harper \& Brothers.

[32] Wakoli C., (2016). Effects of Workload on the Teachers' Performance in Kanduyi Division, Bungoma District. International Journal of Science and Research (IJSR). Volume 5 Issue 10: 1215-1219.

[33] Yimeng Su (2016).Taylor Scientific Management Theory Carding and Significance of Organization Management. Social Sciences. Vol. 6, No. 4, 2017, pp. 102-107.

[34] Yosua Ardi Pratama dan Rina Ratmawati (2016). Henry Fayol Sebagai Bapak Teori Administrasi Modern. Universitas Negeri Yogyakarta: Projek Sarjana.

[35] Yumeikochi (2011). Teori Manajemen Aliran Klasik/ Tradisional. Retrieved from https://yumeikochi.wordpress. com/2011/04/26/teori-organisasi-klasik/ on 29 November 2018 .

[36] Zainudin, A. (2015). SEM Made Simple. MPWS Publication. Bangi, Malaysia. 